\title{
Fé antropológica como ponte entre fé e ideologia em Juan Luis Segundo
}

\section{INTRODUÇÃO}

A ideologia está presente nas estruturas do pensamento humano, na filosofia, na sociologia, na teologia, bem como nas demais ciências sociais e políticas. Sua etimologia provém das combinações dos termos gregos "eidos", e "logos", "palavra, discurso, conhecimento".

Apesar da ideologia estar ligada às formas de dominação social historicamente encontradas na sociedade orientais e antigas, seu estudo sistemático e sua problemática começaram a desenvolver-se somente a partir do crescimento das cidades burguesas da Europa mediante a desintegração dos estamentos sociais da sociedade feudal. A burguesia européia ascendente se defrontava com sistemas de pensamentos, idéias e representações sociais tradicionais que emperravam a sua emancipação, pois no feudalismo a formação educacional estava sob o domínio do clero. Assim, as idéias e as representações sociais partiam deste. Diante disso, a burguesia, em sua luta pela emancipação, se apoderou do método da ciência empírica. A educação secularizou-se e a burguesia passou a desestruturar e derrubar o sistema especulativo escolástico. Iniciou-se, então, a pesquisa cientifica que possibilitou uma ampliação do conhecimento e da informação sobre o mundo. Logo, a ciência permitiu a busca de um saber mais verdadeiro que antes era desviado pela crença em ídolos e pela falsa argumentação (LENK, 1974, p. 9).

O termo ideologia tem recebido diferentes conceitos dentro do processo histórico até nossos dias. Tão amplo como seu uso é também seu significado. Ele tornouse um termo muito controvertido e, ao mesmo tempo, um fenômeno que reúne vários sentidos. Assim, para um melhor uso e discussão da ideologia, entendemos ser imprescindível verificar suas principais manifestações e usos na da história do pensamento humano.

(1) ALVORI AHLERT. Mestre em Educação nas Ciências, pela UNIJUÍ, RS, Doutor em Teologia, Área Religião e Educação pelo IEPG/EST, RS, Professor Adjunto da UNIOESTE, membro do GEPEFE e do Grupo de Pesquisa Cultura, Fronteira e Desenvolvimento Regional. alvoriahlert@hotmail.com, alahlert@brturbo.com.br, alvoriahlert@yahoo.com.br 


\section{ORIGEM DO TERMO IDEOLOGIA}

A palavra ideologia foi criada e introduzida na teoria por Antoine Destutt de Tracy (1756-1826) que usou o termo no seu livro Elemento s de Ideologia, a partir de 1801. De Tracy buscava uma doutrina filosófica para perceber e descrever a origem e a formação das idéias. A esta ciência das idéias deu o nome de ideologia.

Destutt de Tracy pretendia elaborar uma ciência da gênese das idéias, tratandoas como fenômenos naturais que exprimem a relação do corpo humano, enquanto organismo vivo, com meio ambiente. Elabora uma teoria sobre as faculdades sensíveis, responsáveis pela formação de todas as nossas idéias: querer (vontade), julgar (razão), sentir (percepção) e recordar memória). (CHAUÍ, 1988, p. 22).

Para De Tracy, o termo ideologia ainda não possuía nenhum significado valorativo. Seu significado era genérico na medida em que pretendia ser uma ciência das idéias (MANNHEIM, 1968, p. 97). Esta ciência havia sido proposta pelo filósofo francês Etienne Bonnot de Condillac (1715-1780) que, influenciado pelo estudo do espírito humano como objeto da natureza de John Locke (1632-1704), entendia a origem das idéias como resultado das sensações ou das experiências sensíveis. A partir disso, De Tracy reduzia as idéias à sua origem nas sensações, onde acreditava encontrar o fundamento teórico da sociedade, ou seja, as verdadeiras idéias sobre s dimensões políticas e econômicas da vida social.

A evolução do conceito de ideologia recebeu grandes influências no séc. XVI através da "teoria dos ídolos" desenvolvida por Francis Bacon (1561-1626). Em seu Novum Orgum, Bacon coloca em dúvida o conhecimento das ciências tradicionais: "Era preciso evitar tanto a fé cega na autoridade como a aceitação acrítica de opiniões convencionais" (LENK, 1974, p. 10). Segundo ele, o uso corrente de linguagem tradicional esconde os fatos reais da vida. Nesta linguagem se encontram ídolos, preconceitos e superstições que impedem o verdadeiro conhecimento (MANNHEIM, 1968, p. 87-88). Bacon buscava a libertação da razão diante do dogmatismo eclesiástico. Era necessário libertar a burguesia da falsa consciência promovida, uma postura progressista diante do poder e da dominação social da Igreja do Estado.

A teoria de Bacon impulsionou o iluminismo séc. XVII. Os principais influenciados pelo progressismo de Bacon foram os franceses Claude Adrien Halvetius (1715-1771) e Paul Heinrich Von Holbach (1723-1789). Estes filósofos acreditavam que a fraude, o engano, os preconceitos estava ligados não aos problemas de lógica e teoria do conhecimento, mas às ordens do poder que governam a sociedade no sentido de mantê-la através da inconsciência do povo de sua conseqüente apatia.

[...] os preconceitos atribuídos por Bacon aos homens, em geral, cumprem uma certa função social, na medida em que servem para manter a injustiça e impedir a construção de uma sociedade social racional. "Os preconceitos dos grandes", lê-se em Helvécio, "são as leis dos pequenos"; e, numa outra obra: "... a experiência revela que quase todos os problemas morais e políticos não são 
decididos pela razão, mas pela força. Se é certo que a opinião é soberana, ela só o é, em última estância, nos reinos dos poderosos, que fazem e governam a opinião". (HORKHEIMER \& ADORNO, p. 186)

Mas foi Karl Marx (1818-1883) quem deu um salto qualitativo na análise sobre a questão da ideologia. Para ele, a crítica ideológica passa pela crítica da religião afirmando que, "a crítica da religião é a premissa de toda a crítica". (MARX, 1974: p. 93) É necessário fazer primeiramente a crítica da religião para, a partir dela, poder-se fazer a crítica às demais instâncias da sociedade.

$\mathrm{Na}$ época de Marx a religião era a grande força, envolta em uma tradição em todos os campos ideológicos (cf. ENGELS, 1974, p. 370). Por isso Marx concorda com Feuerbach quando afirma que é o ser humano quem faz a religião, mas não como espécie (indivíduo), como o entende Feuerbach, e sim como sociedade e Estado. É o mundo real que produz a religião. Além disso, Marx acreditava que Feuerbach não percebera que a religião é uma conseqüência das relações econômicas e sociais. Nesse sentido K. Lenk afirma:

A crítica de Marx à ideologia supera em muito a crítica de Feuerbach, enquanto considera que a alienação prevalecente na consciência do homem é somente uma parte da alienação total que sofre a vida humana real na sociedade capitalista, cujo traço principal é a alienação econômica: “A alienação religiosa acontece, como tal, somente no âmbito da consciência, da interioridade do homem, mas a alienação econômica é própria de sua vida real; sua superação abarca, portanto, ambos os aspectos". (LENK, 1974, p. 25)

Daí que Marx questiona Feuerbach dizendo que devemos discutir a religião, mas dentro da realidade, afirmando que, "[...] a crítica do céu se converte na crítica da terra, a crítica da religião na crítica do direito e a crítica da teologia na crítica da política". (MARX, 1974, p. 94)

A religião, entendida como produto da alienação econômica, serve como aparelho ideológico para a dominação de classe. Ela passa a ser um "ópio" que entorpece as consciências das classes dominadas que, assim, não compreendem os mecanismos que causam o sofrimento e a exclusão e, além disso, passam a esperar as soluções de seus problemas descerem do céu.

"A miséria religiosa é, por um lado, a expressão da miséria real e, por outro lado, o protesto contra a miséria real. A religião é o suspiro da criatura oprimida, o coração de um mundo sem coração, assim como é o espírito de uma situação carente de espírito. É o ópio do povo". (MARX, 1974, p. 94)

Acreditamos que nessa afirmação, Marx admite uma função não apenas conservadora da religião na medida em que "ópio" pode significar um estimulante para transformar a religião em instrumento de luta contra a miséria, um ato de protesto real, como algo que aponta para uma realidade fora do real. Por isso faz-se necessário ressignificar a frase "religião é o ópio do povo". É o que propõem Wolfgang Kleinig e Gottfried Stiehler, filósofos da Universidade de Humbold, para quem a 
frase de Marx é apenas um lado de sua crítica religiosa, pois a religião também pode ser um protesto contra a miséria, o sofrimento, um estimulante à solidariedade entre os excluídos. (Cf. LWInformation, 1988, p. 9) Estas ressignificações também foram assumidas na América Latina por tendências da Teologia da Libertação na década de 80, sobretudo na América Central, onde os líderes da Revolução Sandinista afirmavam que a experiência demonstrara que os cristãos, impulsionados pela sua fé, se integravam no processo revolucionário com uma verdadeira militância revolucionária, o que demonstrava que um cristão pode ser crente e temente a Deus e ser um revolucionário conseqüente sem nenhuma contradição.

O espaço desse trabalho não nos permite aprofundar mais tais questões. Entretanto, o posicionamento de Marx nos obriga a concluir que a ideologia em Marx é um sistema de idéias ou representações e normas e da moral que são produzidas por intelectuais, pensadores e ideólogos que pensam a vida real a partir das idéias, ilusões e aspirações da classe dominante. Ideologia é, assim, um instrumento da superestrutura dominante que visa manter no poder esta classe a partir do mascaramento da realidade social, pois sua produção está dissociada da realidade social e concreta, ou seja, da produção material. Neste sentido, é uma crítica "[...] que desce do céu à terra" (MARX \& ENGELS, 1982, p. 14) e, portanto, uma consciência invertida.

"Se em toda a ideologia os homens e suas relações aparecem de cabeça para baixo como numa câmera escura, é porque este fenômeno deriva do seu processo histórico de vida da mesma maneira que a inversão dos objectos na retina deriva do seu processo directamente físico de vida". (MARX \& ENGELS, 1982, p. 14)

Em suma, ideologia em Marx é uma falsa consciência ou um conjunto de idéias especulativas, idealistas e metafísicas, produzidas pelo ser humano, isolado da práxis, através da filosofia, da teologia, da política, da economia e das demais representações sociais formuladas pelo pensamento. Visa, pois, encobrir a realidade de dominação e fazer as pessoas crerem que são iguais e que têm as mesmas chances e os mesmos direitos. E a transformação das idéias da classe dominante em idéias universais para a classe subalterna não perceba a luta de classes e, assim, não radicalize esta luta no sentido de tomar o poder.

\section{FÉ ANTROPOLÓGICA E IDEOLOGIA NA OBRA DE JUAN LUIS SE- GUNDO}

Na primeira parte do texto constatamos que o uso do termo ideologia sofreu alterações substanciais na história. Usado exclusivamente por Marx num sentido crítico, ou seja, um sentido pejorativo que denunciava a estrutura de pensamento elaborada pela burguesia (ou por seus ideólogos) para encobrir a realidade mediante a produção de falsa consciência, o termo evoluiu no próprio marxismo a ponto de significar também uma arma num sentido positivo, isto é, um instrumental revolucionário, uma ideologia revolucionária que impulsiona a classe oprimida para um 
projeto e uma luta de libertação. De outro lado, a burguesia também passou a fazer uso do termo para acusar, assim o próprio marxismo de ideológico e manipulador das massas, conforme Mannheim. Além disso, ou a partir disso, se assim se quiser, surgiu a concepção total de ideologia no método de sociologia do conhecimento de Mennheim. Assim, verifica-se hoje uma verdadeira confusão quanto ao uso do termo ideologia. Marxistas e liberais, revolucionários e conservadores usam o termo para se atacar e denunciar mutuamente, sem, muitas vezes, conceituar devidamente o termo. Hoje, o uso de ideologia é atribuído a qualquer sistema de pensamento, isto é, cada classe social possui sua própria ideologia. Portanto, o termo conserva um duplo sentido, ou seja, negativo e positivo.

Este amplo uso do termo ideologia penetrou também o campo das discussões teológicas. Sua caracterização tomou corpo essencialmente com o advento da Teologia da Libertação que assume o marxismo como um instrumental teórico de análise da sociedade, pois entende que a sociologia marxista possibilita uma compreensão mais clara da realidade social a partir da qual nasce a reflexão da fé dos cristãos. Diante disso, a teologia tradicional acusa a nova teologia de ideológica, isto é, marxista, enquanto que esta acusa a tradicional de liberal.

Dentro da própria Teologia da Libertação não encontramos um conceito unívoco de ideologia. Enrique Dussel, por exemplo, conserva basicamente o conceito de ideologia de Marx. Em sua teoria da dependência /opressão centro/periferia. Dussel entende que o centro justifica sua posição encobrindo a realidade através de sua filosofia ontológica. Esta crítica faz ao imperialismo capitalista, a quem chama de "imperialismo ideológico", e também ao "[...] marxismo que não redefine os seus princípios a partir da dependência (5.9.1.2-5) torna-se ideologia encoberta”. (DUSSEL, s.d. p. 10) Assim, mantém o conceito de Marx, isto é, "[...] ideologia - como encobrimento da realidade da dominação"(DUSSEL, 1987, p. 44). Já Hugo Assmann entende ser fundamental, por um lado, manter o conceito negativo de ideologia para desmascarar a ideologia dominadora, mas, por outro lado também empregar o seu sentido positivo, isto é, ideologia como opção de classe junto aos oprimidos.(ASSMANN, 1981, p. 53) Também João B. Libâneo não confere um duplo sentido a este termo:

[...] a ideologia se presta a dois usos bem diferentes, que vão definir a sua relação crítica com a fé. No momento em que ela carrega germes libertários, com conteúdos válidos, a ideologia tem a função de mobilizar forças revolucionarias para criar uma nova situação. [...] No momento, porém, em que o processo revolucionário terminou e entra em fase de institucionalização, cristalização, a ideologia inverte a sua função social. Passa a ser força justificadora da dominação presente, defensora da situação, apresentando, como válidos para todos, os interesses daquele grupo que detém o poder. (LIBÂNEO, 1985, p. 58)

Vemos, pois, que o uso do termo ideologia difere até dentro de uma "única" corrente teológica, a Teologia da Libertação. Cada autor, ou talvez, cada tendência desta teologia imprime uma conceituação particular ao referido termo. Sendo assim, queremos buscar, de forma mais detalhada, a acepção do termo e sua relação com a 
fé em um dos principais representantes da Teologia da Libertação latino-americana, o teólogo uruguaio Juan Luis Segundo. O autor é um profundo conhecedor das diferentes áreas especializadas do estudo. Em seus escritos encontramos discussões com a antropologia, a exegese, a epistemologia, a ecologia, a teoria evolucionista, a dogmática, a teoria marxista, etc. Por isso julgamos elucidar seu conceito de fé e de ideologia, bem como a relação que estabelece entre ambas.

\subsection{Conceito de fé em Segundo}

Para Segundo é fundamental suspeitar da tradicional separação que se estabelece entre fé e ideologia. A maneira de ver as pessoas com relação à fé e a ideologia é a de que os seres humanos se dividem entre os que têm fé e os que têm ideologia. A partir desta separação as pessoas se combatem mutuamente, cada uma procurando superar ou excluir a outra.

Para esclarecimento do problema Segundo propõe uma nova maneira de interpretar a relação entre fé e ideologia, um novo enfoque metodológico. O autor entende não ser conveniente buscar a solução através de definições, mas partindo de análise fenomenológica (SEGUNDO, 1985, p. 3). Propõe, pois, a antropologia como ponto de partida. Esta análise começa com uma interpretação da obra de teatro Calígula, de A. Camus.

Calígula é um personagem preocupado essencialmente com o problema da felicidade do ser humano. Este (o ser humano) coloca toda sua confiança em um caminho escolhido anteriormente. Porém, ao final da vida não se sente realizado, feliz. Para Calígula isto ocorre porque o ser humano se distrai com minúcias e valores secundários, não caminhando concretamente para o objetivo desejado. Por isso o personagem decide se livrar de todos e de tudo que possa atrasa e ou impedir a escolha do melhor caminho a seguir. Mas, ao chegar ao fim da vida constatou que havia gastado todo seu tempo para ganhar a liberdade para efetivar a melhor escolha, não chegando nem a escolher o seu caminho. (SEGUNDO, 1985, p. 3-5; 1975, p. 84-85; 1978, p. 114)

Esta busca da felicidade pelo ser humano torna-se, assim, a chave para a antropologia de Segundo. O personagem de Camus é esclarecedor no sentido de mostrar que "[...] nenhum ser humano pode experienciar vivamente se e como a vida vale a pena ser vivida”.(SEGUNDO, p. 114) Está claro que não é possível para i ser humano fazer experiência sobre um determinado caminho e depois voltar para trilhá-lo, conseguindo evitar os erros e atrasos. Está provado que somente é possível trilhar um único caminho. E sem colocar um objetivo na vida, um caminho que dê sentido à vida, não se pode encontrar a felicidade. Por isso, Segundo entende que é necessário que o ser humano dê uma estrutura de significação à sua vida, para alcançar um fim desejado. Esta estrutura, por sua vez, necessita ser construída a partir de algo concreto para que se possa ter a confiança mínima neste caminho que foi escolhido. O algo concreto é encontrado mediante experiências alheias, o que é possibilitado pela solidariedade, própria do ser humano.

Para Segundo toda a existência humana é necessariamente social. Por isso, a estrutura de valores que cada um se coloca deve encontrar uma certa confirmação de suas reais possibilidades, o que a leva a crer em testemunhas que já realizaram 
determinadas experiências, já percorreram os caminhos escolhidos. Estas testemunhas são as testemunhas referenciais. (SEGUNDO, 1985, p. 9) A confiança nestas é definida pelo autor como um ato de fé individual. O individualismo é uma postura social do ser humano e fruto da sociedade em que se vive, è por isso que sociedade significa fé na compreensão de Segundo. Fé não no sentido religioso, mas no sentido antropológico, universal. (SEGUNDO, 1985, p. 10) Ele caracteriza bem esta sua compreensão em forma de perguntas em sua discussão com Hugo Assmann sobre a contribuição cristã específica num processo revolucionário, na sua obra Massas e minorias na dialética da libertação:

Como explicar este compromisso com o inverificável, a não ser falando, em sentido muito preciso, embora antropológico e não teológico, da fé? De uma fé absolutamente geral, compartilhada por crentes e ateus e sem a qual nenhum homem elaboraria um projeto existencial onde alguns valores condicionam outros até chegar a um valor incondicionado, absoluto? (1975, p. 86)

Esta estrutura de valores que rege a existência humana é fixada pelo próprio ser humano basicamente na fase da adolescência. Na fase infantil a criança coloca toda a sua confiança nos pais e educadores, ou seja, na estrutura de valores destes. É uma confiança que não é questionada, cega. Porém, na adolescência o jovem se auto-descobre. Esta descoberta do "eu" leva à procura de uma nova fé (antropológica) que permite construir uma identidade própria e uma estrutura de valores própria. Segundo escreve em seu livro Libertação da teologia:

[...] é precisamente na adolescência que se tomam as opções básicas pró ou contra a libertação, [...] a imensa maioria dos chamados cristãos ou marxistas, ou seja o que for, não ultrapassa no resto de suas vidas, este nível. Viver a fé [...] conscientemente e até suas últimas conseqüências respectivas é o caso de poucas pessoas maduras.(SEGUNDO, 1978, p. 116)

Portanto, para Segundo, a fé é uma dimensão antropológica inerente a todo o ser humano, seja cristão, budista, ateu marxista, ateu secularizado, etc. Porque a fé é uma estrutura de valores significativos para existência humana, que mostra a cada um o que deve fazer e como deve estruturar a sua vida, além de ser um princípio cognoscitivo que permite distinguir o que é importante para cada um. As longas citações que seguem resumem bem o seu conceito universal de fé:

[...] a fé (em seu sentido mais amplo e leigo) constitui um componente indispensável -uma dimensão- de toda existência humana. Em outras palavras: uma dimensão antropológica. Poderíamos dizer que, contrariamente ao que se poderia supor, cada homem necessita de testemunhas referenciais para articular o mundo dos valores e que o critério que o faz aceitar ou rechaçar tais testemunhas (e seus testemunhos sobre as satisfações possíveis) só pode chamar de fé. (SEGUNDO, 1985, p. 31)

[...] a fé é a dimensão antropológica ligada com a significação global da existência em cada homem. Em certo sentido, isto equivale a dizer que a fé é 
muito afim, em seu conteúdo, com uma escala de valores, ou que é seu próprio fundamento. Em palavras mais existenciais, dizer escala de valores é dizer que preços um homem está disposto a pagar por aquilo que estima e deseja. E que preços, é claro, não está disposto a pagar no jogo das mediações, porque tal preço levaria consigo uma parte do "incondicionado", do que não está à venda, do que não pode ser convertido em condição para nenhuma outra coisa. (SEGUNDO, 1985, p. 76) (70)

Esta fé antropológica que tem a função de dar uma estrutura significativa à existência humana, hierarquiza os valores até alcançar um valor absoluto sob o qual se subordinam todos os demais. (SEGUNDO, 1985, p. 32)

Segundo entende que a dimensão antropológica da fé mostra que esta não é um fenômeno reduzido a grupos religiosos. A partir daí entre em discussão terminológica com W. Pannenberg e De Tracy, que também trabalham com uma dimensão antropológica da fé, porém, sob outra terminologia. Para Pannenberg trata-se de uma “[...] confiança fundamental”. (SEGUNDO, 1985, p. 67) Já para De Tracy, fé antropológica equivale a religião. (SEGUNDO, 1985, p. 69)

Para Segundo, a proposta de Pannenberg realmente trata de uma dimensão antropológica, pois a fé para este "[...] constitui uma condição de toda existência e atividade humanas". (SEGUNDO, 1985, p. 67) Também converge com Pannenberg sobre o, "[...] fato de que a confiança de que fala o autor supera claramente o plano da "eficácia"”. (SEGUNDO, 1985, p. 68) Mas ao mesmo tempo aponta para as divergências que impedem dar à fé antropológica o sinônimo de "confiança fundamental". Os termos "confiança" e "fé", por mais próximos que se encontrem na terminologia usual, não possuem fundamentalmente o mesmo significado, porque "[...] o primeiro conota mais um tom vital do indivíduo e o segundo uma determinada relação entre pessoas". (SEGUNDO, 1985, p. 68)

Quanto à terminologia de De Tracy, Segundo concorda que na análise da "religião" De Tracy se encontram também os sinônimos "fé" e "confiança". "Além disso -escreve ele- a 'religião', do mesmo modo que a fé, revelam seu caráter de dimensão geral (antropologia) somente mediante uma análise fenomenológica". (SEGUNDO, 1985, p. 69) Contudo, assim como a "confiança" de Pannenberg, a "religião" De Tracy também não significa "[...] uma relação pessoal intramundana nem, portanto, social”. (SEGUNDO, 1985, p. 70) Por isso também não serve para distinguir fé de ideologia. Outra dificuldade constatada por Segundo na análise de De Tracy é que este intenta dar um sentido implícito ao termo "religião", enquanto que no uso mais comum este termo significa "[...] um plano explícito com dogmas, ritos e símbolos”. (SEGUNDO, 1985, p. 70) Desta forma a análise de De Tracy se limita ao ser humano que se diz religioso. Estás, pois, excluído o nãocrente dessa análise.

Ehm resumo - diz Segundo-, para os homens que são chamados -e se chamam a si mesmos- "religiosos", a religião pertence, em primeiro lugar e pela regra geral, à ordem das mediações, quer dizer, ao plano da eficácia (de uma eficácia mágica, que precede, no desenvolvimento humano, à eficácia científica). Daí o mal-entendido que surge do fato de a identificar com a fé (antropológica) que, 
como temos visto, determina precisamente o mundo dos valores e sua hierarquia, e não o mundo da eficácia. (SEGUNDO, 1985, p. 71)

Mas qual a relação entre uma fé antropológica e uma fé religiosa, ou, mais especificamente, a fé cristã? Segundo constata que os teólogos têm se apressado em demasia ao diferenciar estas "fés", atestando que a fé antropológica está centrada num caminho do próprio ser humano, enquanto que a fé cristã está centrada em deus e na sua revelação. (SEGUNDO, 1975, p. 87)

Para Segundo, a fé antropológica pode vir a se tornar uma fé religiosa, sem abandonar sua funcionalidade, isto é, uma estrutura de valores. Contudo, há duas possibilidades de se analisar esta relação: a tradicional que acredita numa fé relacionada com Deus somente quando a fé antropológica for superada; ou, uma segunda possibilidade, quando a fé antropológica possui certas qualidades atribuíveis ou não a Deus. (SEGUNDO, 1985, p. 78)

O autor opta pela segunda possibilidade, pois acredita que a revelação de Deus na qual nos fiamos é transmitida por testemunhas humanas. Temos nossa fé em Deus a partir de seres humanos, por exemplo, nos discípulos de Jesus. Eles nos transmitiram a revelação. Aqueles que na época de Jesus o aceitaram como revelação de Deus já possuíam valores da estrutura que ele apresentava. Jesus não veio trazer valores totalmente novos. Para transmitir sua mensagem e convencer com a mesma ele apela para valores pré-existentes ("Reino de Deus", "boa notícia", etc.) aos quais Segundo denomina de "dados transcendentes". Diante desses dados, Jesus exige uma conversão na qual esta estrutura de valores se transforma numa estrutura superior que permite crer em valores não passíveis de serem verificados na experiência humana, "(como a vitória do amor sobre a morte, a igualdade radical de possibilidades para todos os homens, etc.)". (SEGUNDO, 1985, p. 104) Assim, Jesus significou a continuidade de valores que foram criados por um grupo de seres humanos unidos pela sua fé antropológica e que se baseavam no processo de aprender a aprender, pois depositavam a fé em pessoas que mantiveram valores num processo de mudanças, erros, acertos e incertezas. (SEGUNDO, 1985, p. 96)

Conforme Segundo, Jesus fundamenta estes dados transcendentes na tradição registrada no Antigo Testamento, ao anunciar que "[...] o tempo está cumprido" (A Bíblia Sagrada, Marcos 1.15) Jesus também cita largamente o Antigo Testamento aderindo, assim, às tradições representadas por Moisés, isto é, à história na qual os seres humanos aprenderam a aprender a partir da experiência de outros. As pessoas encontraram em Jesus os dados transcendentes de seu próprio quadro de valores.

Portanto, segundo responde a questão levantada acima dizendo que é possível constatar, através de uma exegese da pregação de Jesus, que

[...] uma fé (antropológica), sem perder seu caráter, pode se tornar fé religiosa [...]. Nessa exegese encontramos dois elementos constitutivos de tal fé: a transmissão de dados transcendentes, decisivos para o mundo de valores, e a adesão a uma tradição de testemunhas referenciais de aquisição e experiências desses dados. Somente quando estes dois elementos estão presentes, falaremos -com certa precisão- de "fé religiosa". (SEGUNDO, 1985, p. 103-104) 
Assim, conforme Segundo, a fé não é uma categoria necessariamente religiosa. Antes de uma fé religiosa, existe uma fé antropológica inerente a todo o ser humano. Uma fé universal que dá sentido -a fé antropológica equivale a sentido- à vida das pessoas. Esta fé é uma estrutura de valores significativos que orientam e dão consistência à existência humana. Por isso, tanto religiosos como ateus possuem fé, isto é, fé antropológica, não religiosa. O que, no entanto, os distingue é que a fé religiosa é o resultado de dados transcendentes fundamentados em tradições, enquanto que a fé antropológica se limita a testemunhas referenciais históricas.

\subsection{Conceito de ideologia em Segundo}

Em sua palestra sob o título As elites latinoamericanas: problema humano e cristão em face da mudança social, proferida no Encontro de El Escorial, em 1972, Segundo constata que, "[...] a teologia e a pastoral cristãs foram 'ideologizadas' ao longo da história”. (SEGUNDO, 1977a, p. 180) Este cristianismo serviu às elites para se manterem na condições de incluídos, privilegiados do sistema de político e social do Ocidente, justificados por uma teologia ideologizada. Por isso segundo entende que o processo de libertação requer uma tarefa impostergável, a da desideologização da fé cristã. Esta tarefa, porém, é papel de uma minoria consciente, pois há muitos teólogos ingênuos que ainda entendem a teologia como um trabalho acima de qualquer influência. Nesse sentido faz dura crítica ao teólogo europeu Schillebeeckx:

Um teólogo europeu de linha avançada, Schillebeckx, em Resposta aos Teólogos, mostra-se nisso tão ingênuo a ponto de afirmar que nunca pode a teologia ter função ideológica (de encobrir e justificar a realidade) porque não faz outra coisa que ver a realidade com os olhos da revelação[...]. Como se o trabalho teológico se fizesse em laboratório e não em meio aos interesses e pressões sociais. (SEGUNDO, 1977a, p. 182)

Conforme Segundo, uma das formas ideológicas que impedem os cristãos de assumirem uma política clara de libertação e levarem esta até suas últimas consequiências, isto é, de confronto com os poderes de exclusão, é a pretensa unidade dos cristãos.

A tão propalada "unidade dos cristãos", com suas conseqüências pastorais, constitui claro elemento ideológico. O ideal da unidade para a libertação transformou-se no ideal da unidade para encobrir os conflitos, minimizá-los ante outra coisa declarada mais importante e servir assim, de modo indireto, à manutenção do status quo. (SEGUNDO, 1977a, p. 186)

Portanto, num primeiro momento Segundo assume o conceito marxista de ideologia. Compreende a ideologia como um sistema de idéias que encobre a realidade social de exclusão, fazendo as pessoas acreditarem serem iguais e unidas. Por isso, Segundo acredita na impostergável tarefa da teologia e dos teólogos latinoamericanos de desideologizar a fé cristã. Para essa tarefa reivindica a parceria da sociologia do conhecimento. Caso contrário o teólogo terá que se limitar a apenas des- 
confiar da função ideológica da pregada "unidade dos cristãos". Ele entende haver dois caminhos da sociologia a serem seguidos: em um extremo está a sociologia funcionalista ou positivista norteamericana e, noutro extremo, a sociologia marxista. Ele propõe a segunda opção. Entretanto, aponta para as deficiências dessa sociologia no que tange a análise ideológica da religião. Trata-se de basicamente duas deficiências: "A sociologia marxista não é conseqüente em sua aplicação do conceito de ideologia aos fenômenos religiosos", e "[...] não aceitou metodologicamente a relativa autonomia dos níveis superestruturais”. (SEGUNDO, 1977b, p. 260-261) Para Segundo, não está totalmente claro em Marx se a religião é uma superestrutura igual à arte, política e filosofia. Entende ser quase inquestionável seu caráter de superestrutura. No entanto Marx lhe dá um tratamento diversificado das demais superestruturas. Entende que a superestrutura religiosa desaparecerá com o advento da sociedade capitalista. Porém, o mesmo fim não prevê para a arte, a política e a filosofia. Por isso, no entender de Segundo, Marx não crê na possibilidade de desideologizar a religião como é o caso com as demais superestruturas. E isso causa um impasse para a teologia. O cristão passa a ser visto simplesmente como um aliado tático para um processo emancipatório latinoamericano.

Além disso, o materialismo proposto por Marx constitui-se da lei de que a sociedade está formada por uma infra-estrutura econômica e uma superestrutura ideológica. Sendo que a infra-estrutura determina a superestrutura. Daí que para Segundo, a sociologia, tomando esta proposição ao pé da letra, não lograria outro papel senão o de constatar meramente o tipo de superestrutura em diferentes relações de produção. Assim, a concepção radical e mecanicista do marxismo dogmático não concebeu nenhum papel para a religião.

Entretanto, o próprio Engels já contestava o mecanicismo afirmando que nem ele nem Marx jamais afirmaram tal determinismo econômico, mas que somente em última instância a superestrutura é determinada pelo econômico. Por isso uma visão mais elástica da questão proporcionaria uma relativa autonomia à superestrutura. Conseqüentemente, tal autonomia deveria estar reservada também para a religião, ou que, por sua vez, a sociologia marxista não possibilita. Por isso Segundo opta pela antropologia (SEGUNDO, 1977b, p. 262) e pela sociologia do conhecimento de Mannheim, que lhe serve de ponto de partida para seu círculo hermenêutico. (SEGUNDO, 1978, p. 12)

Diante disso, Segundo propõe um conceito mais amplo de ideologia. Um conceito que vá além do conceito valorativo de Marx. Para isso se fundamenta na terminologia de Mannheim (SEGUNDO, 1978, p. 110-111), que lhe possibilita a seguinte definição para ideologia: "[...] sistema de fins e meios que é condição necessária para [...] a ação humana”. (SEGUNDO, 1978, p. 111) Assim como conferiu uma dimensão antropológica ao conceito de fé (dimensão de sentido), confere também à ideologia esta dimensão antropológica, ou seja, dimensão de "eficácia". Afirma Segundo:

[...] chamaremos desde já ideologia a todos os sistemas de meios, naturais ou artificiais, em vista da consecução de um fim. [...] ideologia é um conjunto sistemático daquilo que queremos de maneira hipotética, não absoluta: em outras palavras, é todo o sistema de meios. (SEGUNDO, 1985, p. 21) 
Desta forma o conceito de ideologia adquire um significado de eficácia no sentido de uma experiência subjetiva que engloba métodos, técnicas, ciências, e que permite dominar os fatos apreendendo o real. Conseqüentemente, "ideologia designa [...] uma visão das coisas que pretende ser objetiva, quer dizer, não valorativa". (SEGUNDO, 1985, p. 22) Contrário, pois, ao conceito pejorativo de Marx que significa um conceito valorativo (negativo).

Segundo entende que seja possível encontrar vários significados do termo ideologia em Marx, na sua abundante obra legada à pesquisa. Contudo, o uso corrente do termo possui dois significados a partir de Marx: um neutro, não valorativo, e outro caracteristicamente valorativo. A acepção negativa, porém, se sobressai em Marx, pois desde o início ele já concebia a ideologia como um valor negativo. (SEGUNDO, 1985, p. 119-120) Esta dupla acepção do termo é retomada por Segundo em sua discussão com o cardeal Josef Ratzinger, hoje Papa Bento XVI, em seu livro Teologia da Libertação - Uma Advertência à Igreja. (SEGUNDO, 1987) Nesta obra questiona o uso do termo ideologia conforme o encontra no documento Instrução sobre alguns aspectos da Teologia da Libertação, elaborado e publicado pela Comissão para a Doutrina da Fé, presidida na época por Ratzinger. Neste escrito Segundo apresenta as duas acepções do termo: uma estrita e negativa, e outra, ampla e neutra.

Estrito, porque não se aplica indistintamente a qualquer pensamento ou sistema de pensamento. Negativo, porque somente se aplica a uma deformação da realidade provocada inconscientemente por interesses criados dentro da sociedade. nesta acepção, ideologia significa falsa consciência social. [...] Ampla, porque cabe nela todo o tipo de sistemas de pensamento e de ação ("ideológicos" ou "anti-ideológicos"). Neutra, porque não se pretende com essa palavra classificá-los como bons ou maus, falsos ou verdadeiros. Simplesmente se alude com isso ao fato de que distintos sistemas de pensamento e ação agrupam e dividem os homens. (SEGUNDO, 1987, p. 50-51)

Temos, portanto, um duplo conceito de ideologia em Segundo. Por um lado o autor reconhece o termo no sentido marxista empregando-o inicialmente. Compreende ideologia como um conjunto de idéias que encobre a realidade de dominação, isto é, uma falsa consciência social. Esta acepção é negativa. Porém, por outro lado, propõe um conceito mais amplo de ideologia. Uma acepção que possui uma dimensão antropológica de eficácia. Assim, a ideologia é para Segundo um sistema de fins e meios necessários para o agir dos seres humano. Para, conforme suas antropologias, alcançar a felicidade, ideologia é qualquer sistema de pensamento que integra, agrupa ou divide os seres humanos, o que significa que ideologia não possui um caráter valorativo, mas neutro e universal.

\subsection{Relação entre fé e ideologia em Segundo}

Conforme já colocávamos anteriormente, Segundo põe seriamente em dúvida a tradicional separação que é feita entre fé e ideologia. Diante deste problema, Segundo sugere conceitos alternativos para ambas as categorias. Vejamos, pois, como 
estes conceitos podem contribuir para uma resposta frente à questão da relação entre fé e ideologia.

Sendo a fé antropológica uma estrutura significativa de valores que dá sentido à vida do ser humano e o impulsiona para a busca da felicidade, ela necessita, pois, de uma maneira ou forma para realizar seu objetivo. Este instrumental é a ideologia enquanto dimensão antropológica de eficácia. Por isso Segundo entende que uma tentativa "[...] de separar fé de ideologia para preservar aquela, está destinada a esvaziar e a matar a fé, a mesma que se pretendia preservar". (SEGUNDO, 1985, p. 160)

Entretanto, isto não significa que a fé e ideologia sejam a mesma coisa. É fundamental distinguir uma categoria da outra. Apesar de Segundo, ao falar sobre a contribuição cristã específica em um processo revolucionário, partir das ideologias como algo prévio ao compromisso, (SEGUNDO, 1978, p. 108ss) ele se obriga a reinterpretar estas ideologias prévias dando-lhes o conceito de fé antropológica para, assim, distinguir claramente fé de ideologia. A diferença básica consiste em qual fé remete a valores e princípios absolutos, enquanto que a ideologia se movimenta em torno de valores relativos. "Reconhecemos uma ideologia - diz Segundo- por suas não pretensões a um valor absoluto objetivo. [...] Reconhecemos, por outro lado, uma fé por suas pretensões a um valor absoluto". (SEGUNDO, 1978, p. 118) Por isso a concretização dessa fé necessita passar pela mediação dos conteúdos, ou seja, mediação da ideologia. "Em outras palavras, a fé é um processo libertador, e se converte assim em liberdade para a história, isto é, liberdade para as ideologias". (SEGUNDO, 1978, p. 122)

Nesse sentido a relação que se estabelece entre fé e ideologia é que a fé é sempre uma opção básica que se encontra em primeiro plano na vida do ser humano em busca de sua felicidade, enquanto que a ideologia vem em segundo plano como instrumento ou ponte para concretizar historicamente as ações humanas motivadas pela fé. (SEGUNDO, 1978, p. 129)

A fé em sua liberdade para com as ideologias parece adquirir em Segundo uma autonomia tal a ponto de ele afirmar: "A fé não é ideologia, é certo, mas só tem sentido como fundadora de ideologias". (SEGUNDO, 1978, p. 120) Para ele este é o caso da fé religiosa. O apóstolo Paulo, captando profundamente a polêmica de Jesus frente à religião de sua época (esta, de fé se transforma em ideologia), entende ser a fé a justificação do ser humano (A BİBLIA, Rm 3.28), sem, porém, desprezar as obras. No entanto, as obras não substituem a fé, mas vem a partir dela.

Com efeito, o problema de Paulo não consiste em saber se é necessário privilegiar o "crer" frente ao o "obrar". Contrariamente à interpretação luterana -e, por refutá-la, também a católica tradicional-, se é verdade que a salvação, na concepção paulina vem da fé apenas, isso sucede porque a fé permite atuar, agir de uma determinada maneira. (SEGUNDO, 1985, p. 150-151)

Este agir equivale à realização de obras o que significa, em outras palavras, eficácia ou conjunto de valores, mostrando que a fé, neste caso, é fundadora de uma ideologia religiosa. 


\section{CONSIDERAÇÕES FINAIS}

A discussão estabelecida por Segundo sobre a relação entre fé e ideologia lhe permite afirmar que a fé sem ideologias não é fé e que uma ideologia sem fé também não é ideologia. Nesta relação entre fé e ideologia fica clara a necessidade da fé se encarnar em ideologias. Segundo demonstra isso citando o exemplo negativo da questão histórica ocorrida no Chile (SEGUNDO, 1978, p. 143-146). Quando a Unidade Popular, coalizão de partidos socialistas apoiados inicialmente pela igreja, chegou ao poder teve que se encaminhar necessariamente para a construção do socialismo. A igreja, porém, no momento decisivo desse embate retirou seu apoio. Ao fazer isso buscava eximir-se de qualquer posição ideológico. Contudo, ao não fazer a opção pró-construção socialista, optava ideologicamente pelo capitalismo de mercado sustentado na ditadura militar.

Segundo constatou a dificuldade de uma opção ideológica na América Latina como consequiência de uma profunda destruição ecológica: "a destruição da ecologia social”. (SEGUNDO, 1985, p. 355) (2) (123) Por essa destruição ecológica culpa tanto ao marxismo quanto ao liberalismo, que em suas tentativas unilaterais terminam "[...] destruindo de alguma forma a relação básica entre o homem e seu ambiente, seja este biológico, seja social”. (SEGUNDO, 1985, p. 383) Por isso entende ser necessário relacionar ideologia com ecologia para cumprir a tarefa que se coloca para o continente latinoamericano que é a "[...] de criar ou recriar cultura" (SEGUNDO, 1985, p. 406), pois somente a partir da reconstrução da ecologia social, isto é, "[...] do homem e da sociedade a partir de sua base social[...]"(SEGUNDO, 1985, p. 383), a possibilidade de uma opção ideológica poderá se tornar conseqüente.

Concluímos, assim, que a relação que o autor estabelece entre fé e ideologia continua sendo uma descoberta extremamente importante no momento em que ideologias de emancipação e libertação se rearticulam em toda a América Latina através de governos de esquerda e centro esquerda em vários países (Brasil, Uruguay, Ecuador, Venezuela, Bolívia, Nicarágua). Ao afirmar que a fé sem ideologia é morta e, vice versa, a teoria de Segundo fornece uma sustentação para que a teologia encoraje novamente as pessoas para que, a partir de sua fé, se engajem no fortalecimento desses projetos políticos em construção e fomentem a busca desses processos também nos outros países.

Contudo, cabe lembrar que toda a opção ideológica no contexto da religião cristã sempre possui apenas um caráter histórico. Ideologias sempre serão produções humanas e, por isso, suscetíveis de erros e corrupções. Nesse sentido, a fé cristã deve permanecer sempre com a função crítica de resguardar esse caráter histórico e humano da ideologia, pois a esperança cristã não se absolutiza em ideologias. A esperança cristã não busca somente uma libertação histórica e estrutural, mas é esperança por uma libertação integral. Uma libertação que purifica de tudo o que destrói, oprime e exclui o ser humano, como o medo, a doença, a morte.

(2) Segundo explica detalhadamente este conceito de ecologia fundamentado em G. Bateson, com o qual vem em conversação ao longo desta obra e ao qual ele mesmo denomina de neopositivista. (SEGUNDO, 1985, p. 138) 


\section{REFERÊNCIAS BIBLIOGRÁFICAS}

A BÍBLIA Sagrada. Antigo e Novo Testamento. Brasília: Sociedade Bíblica do Brasil, 1969. ASSMANN, Hugo. A teologia da libertação se opõe aos ídolos da opressão. In: ALVES, Rubem et alii. Fé cristã e ideologia. Piracicaba/São Bernardo do Campo: UNIMEP/ Imprensa Metodista, 1981, pp. 46-67.

CHAUÍ, Marilena de Souza. O que é ideologia. 26 ed. São Paulo: Brasiliense, 1988.

DUSSEL, Enrique. Filosofia da libertação. 2 ed. São Paulo/Piracicaba: Loyola/UNIMEP, s.d.

Ética comunitária. 2 ed. Petrópolis: Vozes, 1987.

ENGELS, F. Ludwig Feuerbach y el fin de la filosofia clásica alemana. In: ASSMANN, Hugo; MATE, Reyes (Comp. ). Sobre la religión. Salamanca: Sígueme, 1974, pp. 329371.

Correspondência a J. Bloch. In: ASSMANN, Hugo; MATE, Reyes (Comp. ). Sobre la religión. Salamanca: Sígueme, 1974, pp. 442-446.

HORKHEIMER, Max \& ADORNO, Theodor W. (orgs.). Temas básicos da sociologia. 2 ed. São Paulo: Cultrix, s.d., pp. 184-205.

LENK, Kurt. El concepto de ideologia: comentário crítico y selección sistemática de textos. Buenos Aires: Amorrortu, 1974, pp. 9-46.

LIBÂNEO, João Batista. Fé e política: autonomias específicas e articulações mútuas. São Paulo: Loyola, 1985, pp. 11-70.

LÖWY, Michael. As aventuras de Karl Marx contra o Barão de Münchhausen. São Paulo: Busca Vida, 1987.

LWInformation. Lutherische Welt-Information. Gemf/Schweitz, (34), sep. 1988.

MANNHEIM, Karl. Ideologia e utopia. Rio de Janeiro: Zahar, 1968.

MARX, Karl. Teses sobre Feuerbach. In: MARX, Karl \& ENGELS, Friedrich. Obras escolhidas. São Paulo: Alfa-Ômega, s.d. Vol. 3, pp. 208-210.

Prefácio à "Contribuição à crítica da economia política". In: MARX, Karl \& ENGELS, Friedrich. Obras escolhidas. São Paulo: Alfa-Ômega, s.d. Vol. 1, pp. 300-303.

Contribuición a la crítica de la filosofia del derecho de Hegel. In: ASSMANN, Hugo; MATE, Reyes (Comp. ). Sobre la religión. Salamanca: Sígueme, 1974, pp. 93106.

MARX, Karl \& ENGELS, Friedrich. Oposição das concepções materialista e idealista. (Capítulo primeiro de A Ideologia Alemã). In: MARX, Karl \& ENGELS, Friedrich. Obras escolhidas em três tomos. Lisboa: Avante/Progresso, 1982, Vol. 1, pp4-75.

SEGUNDO, Juan Luis. As elites latinoamericanas: problema humano e cristão em face da mudança social. In: INSTITUTO Fé y Secularidad. Fé cristã e transformação social na América Latina. Petrópilos: Vozes, 1977a , pp. 180-188.

Teologia e ciências sociais. In: INSTITUTO Fé y Secularidad. Fé cristã e transformação social na América Latina. Petrópilos: Vozes, 1977b , pp. 253-262.

Massas e minorias na dialética divina da libertação. São Paulo: Loyola, 1975.

Libertação da teologia. São Paulo: Loyola, 1978.

O homem de hoje diante de Jesus de Nazaré. São Paulo: Paulinas, 1985, Vol. 1.

(Fé e Ideologia)

Teologia da libertação: uma advertência à igreja. São Paulo: Paulinas, 1987, pp. 31-57. 


\title{
RESUMO
}

Este texto busca a compreensão da ideologia em sua relação com a fé na teologia latinoamericana a partir da concepção de fé antropológica na obra de Juan Luis Segundo. Acreditamos que a questão da ideologia, e sua relação com a fé, continua sendo uma questão atual no pensamento cristão, face aos velhos e novos problemas humanos que o novo século vem apresentando. Concentramos nossa análise nos escritos de Juan Luis Segundo, um dos principais representantes dessa teologia, por ser este teólogo que, ao nosso ver, mais trabalhou, de forma explícita, a questão da ideologia e sua relação com a fé no contexto latinoamericano.

Palvras-chave: Fé antropológica, ideologia, fé, teologia da libertação.

Palabras clave: Fe antropologica, ideología, fe, teología del liberación.

\begin{abstract}
This text searchs the understanding of the ideology in its relation with the faith in the Latin American theology from the conception of antropology faith in the workmanship of Juan Luis Segundo. We believe that the question of the ideology, and its relation with the faith, continue being a current question in the christian thought, face to the old and new human problems that the new century comes presenting. We concentrate our analysis on the writings of Juan Luis Segundo, one of the main representatives of this theology, for being this theologian who, to ours to see, more worked, of explicit form, the question of the ideology and its relation with the faith in the Latin American context.
\end{abstract}

Key words: Antropology faith, ideology, faith, theology of the release. 